\title{
Food Affordability and Economic Growth
}

\author{
Ruslan Mudrak ${ }^{1}$, Volodymyr Lagodiienko ${ }^{2}$, Nataliia Lagodiienko ${ }^{3}$, Vitalii Rybchak ${ }^{1}$ \\ ${ }^{1}$ Uman National University of Horticulture, 1 Institutska Str., Uman, Cherkasy region, 20305, Ukraine \\ ${ }^{2}$ Odesa National Academy of Food Technologies, 112 Kanatna Str., Odesa, 65039, Ukraine \\ ${ }^{3}$ Mykolayiv National Agrarian University, 9 Georgii Gongadze Str., Mykolayiv, 54020, Ukraine
}

\begin{abstract}
The conducted correlation-andregression analysis revealed a close inverse connection between the functional characteristic "share of the expenditures for food and non-alcoholic beverages in the structure of the total expenditures of the households" and the factorial characteristic "GDP per capita by purchasing power parity, at constant prices". The response of the share of food expenditures in the structure of the total expenditures of the households to per capita GDP growth corresponds to the law of diminishing returns. The pattern is manifested in the long-term period.
\end{abstract}

Keywords - food security, food availability, food affordability, economic growth, law of diminishing returns.

\section{Introduction}

The state of the food security of the country, households and individual is one of the most accurate characteristics of the welfare level of the nation. That what the citizens eat, how much, and what it costs them better than any government report shows the success of the economic model, political system, and reforms launched under the auspices of improving the country's access to the vital economic goods.

The indicators of the social responsibility of the national elites are the current system of the analysis of the food security state, the speed of management response to its violation, the breadth of coverage of

DOI: 10.18421/TEM94-32

https://doi.org/10.18421/TEM94-32

Corresponding author: Ruslan Mudrak, Uman National University of Horticulture, Uman, Ukraine. Email: mrp1974@ukr.net

Received: 06 September 2020.

Revised: 16 October 2020.

Accepted: 22 October 2020.

Published: 27 November 2020.

(cc) BY-NC-ND (C) 2020 Ruslan Mudrak et al; published by UIKTEN. This work is licensed under the Creative Commons Attribution-NonCommercial-NoDerivs 4.0 License.

The article is published with Open Access at www.temjournal.com recipients of food aid and the depth of appropriate financial support.

It is important to note that there is a passing from the concept of the food security to the concept of the food safety in mature societies [10]. They are significantly different. The first is based on the economic approach, which considers food as the object of consumption, the availability of which can be a problem, and therefore puts it in the first place. Instead, the concept of the adequate nutrition is based on the biological approach, the central point of which is the state of human health [13]. In other words, the sufficient amount of food of the corresponding quality under reasonable price is the integral part of the consumer basket of all citizens in the mature societies. With the exception of the marginalized antisocial members of the society being in any country - vagrants, illegal migrants, criminals, lazy people, people with alcohol and drug addiction, and so on. We call democratic countries those with well-developed civic institutions, modern competitive economies, and socially responsible political and economic elites as mature societies. The cultural phenomenon of such countries is the condemnation of any manifestations of restriction of the constitutional rights and freedoms of their citizens. It is first of all, the right to sufficient and adequate nutrition. The problem of food sufficiency and availability is no longer for them, but the problem of how to eat to be a healthy person.

Less successful countries still cannot solve the problem of fully providing their citizens with a sufficient amount of food of appropriate quality and affordable by price. Unfortunately, Ukraine is one of such countries. Of course, countries with food security problems are not homogeneous. The worst consequences of food insecurity - deaths from starvation are in the poorest countries. There is chronic malnutrition in others. And others have temporary problems with food supply [8]. Studies show that Ukrainian citizens do not have problems with the amount of food. Or what is called "food availability". The energy value of the daily diet of the average resident was $2994 \mathrm{kcal}$ in 2017 and $2978 \mathrm{kcal}$ in 2018 on the territory of the country, except for some temporarily occupied districts of Donetsk and Luhansk regions and the Autonomous Republic of Crimea [20]. This is 
more than determined by the Resolution of the Cabinet of Ministers of Ukraine No.780 of October 11, 2016 (2790.8 kcal) [7] and much more than the threshold level of food security set by the Resolution of the Cabinet of Ministers of Ukraine No.1379 of December 5, 2007 (2500 kcal) [6] and FAO [11]. However, there is a problem with food affordability Ukrainian citizens spend almost half of their total expenditures for buying the food products. And although the threshold value of the national indicator of food security according to this criterion is $60 \%$ threshold [6], we consider this situation as the problematic one. It becomes obvious when compared to the countries of the former socialist camp, which had no better starting indicators of the social production than Ukraine at the beginning of reforming their economies in the 90s of the XX century - Lithuania, Hungary, Poland, Czech Republic. In 2018, the analysed indicator was $20.9 \%, 18.1 \%, 16.4 \%$ and $16.0 \%$, respectively [14]. It was $49.4 \%$ in Ukraine [20]. In our opinion, the main reason for such differences is the different rates of the economic growth.

\section{Literature Review}

The connection between the economic growth and food security is a very popular mainstream in the studies of the Western researchers on food theme. The main difference in such studies is that what is considered as a functional and factorial feature. The approach according to which food security is the functional feature, the economic growth - the factorial one, acquired the most spread.

Following the first approach, it should be noted that economic growth, in itself, is not a universal means of improving the level of the food security. The factor of fair distribution of the national income is also of significant importance. However, the connection between increasing the volume of social production and improving household access to the foodstuffs is clearly positive. Stamoulis and Zezza point at it and note that the economic growth not only helps to increase the income and opportunities of the poor to improve access to food products, health service, service industry and overpassing the negative effects of poverty, but also provides governments with the necessary resources to pursue policies for poverty reduction and redistribution, which will make such economic growth much fairer [19]. Breisinger, van Rheenen, Ringler et al. also point at it. They note that the economic growth, which increases people's incomes, is the most important key, a drive of food security [2].

Świetlik points at high potential of the research on the connection between the economic growth and food security. The scientist notes that the economic growth and increase in real income, especially in the poorest countries is the main condition for improving global food security [22].

Timmer points at the key role of the economic growth in poverty reduction and improvement of the food security. The scientist rightly notes that there is a stable relation to economic growth, which leads to increased food security, improves the food needs of the poor [25].

Baldos and Hertel, Barret, Remans, Wood, Saha et al., point at the extremely important role of the economic growth in poverty and malnutrition reduction in the countries with low and middle income [1], [3], [17].

Choudhury and Headey put the economic growth in the first place among other factors while studying the factors of diversification in the national food systems [5].

A group of scientists including van Dijk, Gramberger, Laborde et al., note that the economic development (GDP) and changes in income (GDP per capita) will be the main drivers of the sufficient amount of food consumption while developing four scenarios of the global food security for 2050 [26].

According to the second approach - the functional feature is the economic growth, a factorial one is food security. In the context of this approach, the position of the Ministry of International Cooperation of Canada (CIDA) is interesting. Chemin, Pelc and Perez-Aleman note that CIDA focused its assistance efforts on three priority themes: improving food security, ensuring the future of children and young people, and promoting sustainable economic growth. Moreover, the priority of assistance areas is as follows: first - to increase the food security, and secondly - to stimulate the sustainable economic growth. CIDA believes that these priority topics can be considered as separate ones. They simultaneously note that they have many ways of convergence in their goals - to reduce poverty and promote economic development, especially in the rural areas, where the majority of the poor live [4]. We find a similar approach in the Office of Science and Technology of the British Parliament. Here they rightly believe that hunger is the main limitation for the immediate and long-term economic, social and political development of the country. Food security is considered a necessary condition for the economic development. Losses in labour productivity because of the hunger can lead to a decrease in gross domestic product (GDP) per capita by 6-10\%. Nutrient deficiencies in fetal development and early childhood lead to poor cognitive development, which leads to the reduction of the labour productivity and potential of income receiving during the whole life [24].

It should be noted that the second approach is valid for the countries and regions with confirmed cases of temporary or chronic hunger. However, it cannot 
be applied to the countries with sufficient food consumption (in energy equivalent), including Ukraine. This thesis is confirmed by the study of Pourreza, Geravandi and Pakdaman. The researchers note that these are the countries with the very high levels of poverty and chronic malnutrition that face with limits in human capital development, which is a prerequisite for achieving sustainable growth. High level of malnutrition can cause GDP losses from 4 to $5 \%$ [16].

There is a shortage of researches in the domestic expert community on measuring the quantitative connections between the food security and macroenvironmental conditions. Seheda et al. propose to measure the impact of the level of the food security of the Ukraine's population on the birth and mortality rate, life expectancy at birth, infant mortality rate and female fertility coefficient [18]. In other words, the food security acts as an impact factor. Instead, Stezhko examines the connection between the Global Food Security Index and the Global Competitiveness Index, the Corruption Perceptions Index, the Human Development Index and the Environmental Efficiency Index while using a comparative analysis of the food security state of the world countries [21].

Thus, the study of the connection between the economic growth and food security of Ukraine is an urgent scientific problem that needs to be solved.

\section{Aims}

The aim of the study is to check the hypothesis on the presence of the connection between the economic growth and food security in the Ukrainian economy. To achieve this aim, it is necessary to solve the following tasks:

- to substantiate the functional feature as a quantitative parameter of the food security of Ukraine, which most fully characterizes the state of the food supply of the country's population and may depend on the rate of the economic growth;

- to study the connection between the economic growth and food security in the OECD countries;

- to study the connection between the economic growth and food security in Ukraine;

- to compare the obtained results to identify the patterns;

- to substantiate the prospects of increasing the level of the food security of Ukraine, based on the prospects of the economic growth of the national social production.

\section{Methods}

The research methods are: correlation-andregression analysis of the statistical data for 24 years (1995-2018) for 42 countries reflected in the statisti- cal database of the Organization for Economic Cooperation and Development, the World Bank and Ukraine; analytical grouping.

Today, there is no single approach to determining a specific parameter of the food security, which can be used as a functional feature, the variability of which depends on the variability of the influencing factor - the rates of the economic growth, both in foreign and domestic science. For example, Breisinger, van Rheenen, Ringler et al. propose a new typology for the Middle East and North Africa as functional features of the food security: the ratio of total exports to food imports, food production per capita, global hunger index, gross national product per capita [2]. Instead, Świetlik suggests using the value of the Global Food Security Index as a functional feature [22]. Choudhury and Headey propose to use the indicator of food consumption in the energy equivalent as a functional feature [5]. Martinez and Colmenero suggest using the indicator "level of malnutrition" as a functional feature [12].

The diversity of approaches is objective and can be explained by the significant differences in the results of the systems operation of the food supply which are the objects of the study. The choice of such functional features does not correspond to the specific features of the operation of the national food system to study the impact of the economic growth on the food security in Ukraine. In particular, as already mentioned, there are no cases of chronic or temporary malnutrition in Ukraine. Therefore, the indicators of "malnutrition level", "hunger index" and similar indicators are not suitable for our analysis. In our opinion, the most current problem of the food security of the population of Ukraine is the level of the food affordability.

\section{Results}

The current normative document regulating the list of the indicators of the food security of Ukraine and the method of their calculation remains the Decree of the Cabinet of Ministers of Ukraine "Some issues of food security" No.1379 of December 5, 2007 [6]. According to it, the current indicators of the food security are:

1) daily energy value of the human diet;

2) providing the human diet with the main types of products;

3) adequacy of grain stocks in the state reserves;

4) food affordability;

5) differentiation of the food cost by social groups;

6) capacity of the domestic market of particular products;

7) food independence by a particular product. 
Based on the purpose of the study, we will focus only on those indicators that relate directly to the food security of the individual household and the individual - they are 1,2 and 4 indicators.

The first and fourth indicators concern the food availability and food affordability for the country's citizens.
The analysis of statistical data confirmed the as sumption that there are no problems with the food availability in Ukraine - even the poorest citizens consume enough food that eliminates chronic and temporary hunger (Table 1.). Instead, there is a serious problem with the food affordability - despite some improvement, half of the country's population spent more than $50 \%$ of their total expenditures for purchasing food in the reporting period.

Table 1. Dynamics of actual values of the indicators of food availability and food affordability in the households of Ukraine by decile (10\%) groups depending on the size of per capita equivalent total income; on average per day per one person, kcal; on average per month per one household *\% [20]

\begin{tabular}{|l|c|c|c|c|c|c|c|c|c|c|}
\hline \multirow{2}{*}{$\begin{array}{l}\text { Decile } \\
\text { group }\end{array}$} & \multicolumn{2}{|c|}{2014} & \multicolumn{2}{|c|}{2015} & \multicolumn{2}{c|}{2016} & \multicolumn{2}{|c|}{2017} & \multicolumn{2}{|c|}{2018} \\
\cline { 2 - 12 } & kcal & $\%$ & kcal & $\%$ & kcal & $\%$ & kcal & $\%$ & kcal & $\%$ \\
\hline I & 2614 & 62.7 & 2436 & 63.0 & 2459 & 59.2 & 2511 & 59.6 & 2495 & 58.9 \\
\hline II & 2882 & 60.2 & 2763 & 61.6 & 2639 & 57.7 & 2628 & 55.8 & 2798 & 56.7 \\
\hline III & 3028 & 59.4 & 2818 & 59.4 & 2690 & 56.3 & 2763 & 53.7 & 2751 & 53.8 \\
\hline IV & 3112 & 57.3 & 2949 & 57.2 & 2990 & 55.9 & 3016 & 52.7 & 2921 & 54.3 \\
\hline V & 3256 & 56.6 & 3066 & 58.8 & 2928 & 54.0 & 2938 & 51.6 & 3035 & 52.1 \\
\hline VI & 3302 & 53.9 & 3161 & 56.2 & 3050 & 53.2 & 3021 & 51.0 & 2987 & 49.9 \\
\hline VII & 3455 & 53.5 & 3213 & 55.9 & 3150 & 48.8 & 3294 & 52.0 & 3068 & 49.9 \\
\hline VIII & 3523 & 52.3 & 3230 & 53.4 & 3193 & 49.6 & 3218 & 48.9 & 3059 & 46.6 \\
\hline IX & 3605 & 49.1 & 3404 & 51.7 & 3384 & 48.5 & 3293 & 45.9 & 3371 & 47.5 \\
\hline X & 3793 & 44.5 & 3425 & 43.5 & 3583 & 43.0 & 3387 & 39.5 & 3398 & 40.1 \\
\hline
\end{tabular}

* the expenditures for purchasing food and non-alcoholic beverages and meals outside the home

The low level of food affordability or as it is called the Global Food Security Index (GFSI) according to the methodology [23], price affordability of food, is the reason why poor Ukrainian households cannot afford a full balanced diet. In 2018, the households of I-V decile groups consumed meat and meat products, vegetables and cucurbitaceous below the norms set by the government, and the households of I group - consumed fish and fish products, and eggs less. And the consumption of milk and dairy products, fruits, berries and grapes, potatoes was in short supply in the households of all decile groups (Table 2.). Deficit of consumption of the valuable foodstuffs of an animal origin, fresh fruit and vegetables is covered at the expense of cheap carbohydrate products - bread and bakery products, sugar, vegetable fats. The actual values of the second indicator of the food security indicate that the low incomes of the most part of the country's population are the reason of an unbalanced diet.

Analysis of the actual values of the food security indicators in Ukraine confirmed the assumption that the most pressing problem in the food security system of the country at the level of the households and individuals is the low level of food affordability. Therefore, we believe that this indicator should be taken as a functional feature, as a quantitative parameter of the food security of Ukraine, which most fully characterizes the current state of the food security of the country's population, and probably depends on the rates of the economic growth.

Correlation-and-regression analysis as a methodological tool for determining the quantitative connection between the level of food affordability and the rates of the economic growth was used. Studies of Choudhury and Headey indicate to the effectiveness of this approach [5]. And Gödecke, Stein and Qaim using regression analysis conclude that the higher per capita GDP, the lower the burden of chronic and hidden hunger - an increase in GDP by $1 \%$ causes a decrease in chronic hunger by $0.4-0.5 \%$, hidden hunger - by $0.2-0.3 \%$ [9].

The panel data for 24 years (1995-2018) for 42 countries showed in the statistical database of the OECD and Ukraine to measure the studied connection were used. "The share of the expenditures for food and non-alcoholic beverages in the structure of the total expenditures of the households, \%" is taken as a functional feature $(Y)$ [14], "GDP per capita by purchasing power parity, at constant prices $(2010=$ 100), dollars USA" as a factorial feature $(x)$ [15]. The relevant data from the World Bank [27] and the State Statistics Service of Ukraine were used because Ukraine is not a member of the OECD and its macro indicators are not reflected in the statistical base of this organization [20]. 
Table 2. Standard and actual food consumption in the households of Ukraine by decile (10\%) groups depending on the size of the average per capita equivalent total income in 2018, $\mathrm{kg}$ per 1 person per year [7], [20]

\begin{tabular}{|l|c|c|c|c|c|c|c|c|c|c|c|}
\hline \multirow{2}{*}{ Food product } & \multirow{2}{*}{$\begin{array}{c}\text { Stand- } \\
\text { ard [5] }\end{array}$} & \multicolumn{8}{|c|}{ Actual consumption by decile groups } \\
\cline { 3 - 14 } & & I & II & III & IV & V & VI & VII & VIII & IX & X \\
\hline Bread and bakery products & 95 & 93.6 & 99.6 & 96 & 100.8 & 102 & 103.2 & 100.8 & 100.8 & 108 & 99.6 \\
\hline Meat and meat products & 53 & 37.2 & 39.6 & 44.4 & 50.4 & 51.6 & 52.8 & 57.6 & 58.8 & 67.2 & 75.6 \\
\hline Milk and dairy products & 300 & 105.6 & 136.8 & 135.6 & 147.6 & 164.4 & 159.6 & 171.6 & 170.4 & 189.6 & 212.4 \\
\hline Fish and fish products & 13 & 12 & 13.2 & 14.4 & 16.8 & 15.6 & 15.6 & 16.8 & 18 & 21.6 & 21.6 \\
\hline Eggs (pieces) & 220 & 188.4 & 222 & 211.2 & 234 & 229.2 & 235.2 & 244.8 & 248.4 & 252 & 267.6 \\
\hline Vegetables and melons & 110 & 79.2 & 93.6 & 93.6 & 99.6 & 106.8 & 110.4 & 110.4 & 116.4 & 126 & 136.8 \\
\hline Fruits, berries and grapes & 80 & 28.8 & 36 & 37.2 & 40.8 & 43.2 & 45.6 & 48 & 51.6 & 58.8 & 74.4 \\
\hline Potato & 95 & 70.8 & 75.6 & 74.4 & 75.6 & 81.6 & 79.2 & 76.8 & 74.4 & 79.2 & 73.2 \\
\hline Sugar & 24 & 26.4 & 30 & 28.8 & 30 & 33.6 & 32.4 & 33.6 & 33.6 & 37.2 & 37.2 \\
\hline Vegetable oil & 10 & 16.8 & 18 & 16.8 & 18 & 18 & 16.8 & 18 & 16.8 & 20.4 & 18 \\
\hline
\end{tabular}

Correlation-and-regression analysis was conducted, and the countries with a low level of the studied connection $(r<0.5)$ were eliminated at the first stage of the analysis. They are: Israel, Costa Rica, Mexico, New Zealand, South Korea, Greece and Italy. The analytical grouping while choosing the average value of the factorial feature for 1995-2018 as a grouping feature (Table 3.) was conducted at the second stage of the analysis.

Thus, the working hypothesis is confirmed and there is a close connection between the food affordability and economic growth for both OECD countries and Ukraine. It can be formulated as follows - with the growth of the GDP per capita, the share of the expenditures for food and non-alcoholic beverages in the structure of the total expenditures of the household's decreases.

The second, no less important, conclusion is that as GDP per capita grows, the share of the expenditures for food and non-alcoholic beverages in the structure of the total expenditures of the households slows down. This is evidenced by the gradual increase in the average values of the regression coefficient (b) - from the lowest in the countries with the highest level, to the highest one in the countries with the lowest level of GDP per capita. For example, in the first group of the countries, an increase in per capita GDP by 1000 dollars USA reduces the share of the expenditures for food by $0.12 \%$, in the latter by $0.87 \%$, in Ukraine - by $3.8 \%$.

Table 3. Grouping of the countries by average GDP per capita, for the period of 1995-2018, \% [14], [15], [20], [27]

\begin{tabular}{|c|c|c|c|c|c|}
\hline Country & $r$ & $\begin{array}{c}\text { Regression } \\
\text { coefficient, } b\end{array}$ & $p$-Value & $\begin{array}{c}\text { Average value } Y \text { for } \\
1995-2018, \% \\
\end{array}$ & $\begin{array}{c}\text { Average value } x \text { for } 1995- \\
2018, \text { dollars USA } \\
\end{array}$ \\
\hline Luxembourg & 0.797 & -0.00004 & -0.000037 & 9.3 & 80056 \\
\hline Norway & 0.959 & -0.0003 & $1.47 \mathrm{E}-13$ & 13.3 & 56515 \\
\hline Switzerland & 0.761 & -0.00005 & $2.46877 \mathrm{E}-05$ & 9.3 & 51506 \\
\hline USA & 0.942 & -0.00009 & $6.18233 \mathrm{E}-12$ & 6.9 & 47320 \\
\hline Ireland & 0.829 & -0.0001 & $5.45748 \mathrm{E}-07$ & 10.5 & 44422 \\
\hline Denmark & 0.896 & -0.0002 & $3.30523 \mathrm{E}-09$ & 11.7 & 42566 \\
\hline Australia & 0.962 & -0.0001 & $6.57337 \mathrm{E}-14$ & 10.1 & 40706 \\
\hline Austria & 0.958 & -0.0001 & $2.24419 \mathrm{E}-13$ & 10.2 & 40089 \\
\hline On the average & $x$ & -0.00012 & $x$ & 10.2 & 50398 \\
\hline Sweden & 0.587 & -0.00006 & 0.002552274 & 12.4 & 39230 \\
\hline Canada & 0.941 & -0.0001 & 7.86934E-12 & 9.5 & 38980 \\
\hline Iceland & 0.845 & -0.0003 & $2.06933 \mathrm{E}-07$ & 14 & 38816 \\
\hline Germany & 0.759 & -0.0001 & $1.70868 \mathrm{E}-05$ & 10.8 & 38582 \\
\hline Belgium & 0.765 & -0.0002 & $1.33174 \mathrm{E}-05$ & 13.2 & 38225 \\
\hline Finland & 0.784 & -0.0001 & $5.90836 \mathrm{E}-06$ & 12.6 & 35740 \\
\hline United Kingdom & 0.750 & -0.0001 & $2.4548 \mathrm{E}-05$ & 8.5 & 35260 \\
\hline France & 0.745 & -0.0001 & $2.99437 \mathrm{E}-05$ & 13.4 & 35026 \\
\hline
\end{tabular}


TEM Journal. Volume 9, Issue 4, Pages 1571-1579, ISSN 2217-8309, DOI: 10.18421/TEM94-32, November 2020.

\begin{tabular}{|c|c|c|c|c|c|}
\hline Spain & 0.943 & -0.0004 & $5.12746 \mathrm{E}-12$ & 13.6 & 30696 \\
\hline Cyprus & 0.818 & -0.0003 & $1.03128 \mathrm{E}-06$ & 13.5 & 30579 \\
\hline On the average & $x$ & -0.00018 & $x$ & 12.2 & 36113 \\
\hline Malta & 0.910 & -0.0003 & $6.47896 \mathrm{E}-08$ & 13.8 & 28719 \\
\hline Portugal & 0.809 & -0.0004 & $1.72508 \mathrm{E}-06$ & 16.9 & 26155 \\
\hline Slovenia & 0.962 & -0.0003 & $6.95894 \mathrm{E}-14$ & 15.5 & 25431 \\
\hline Czech & 0.692 & -0.0002 & 0.000180953 & 16.1 & 25293 \\
\hline Slovakia & 0.860 & -0.0005 & 7.29532E-08 & 20.2 & 21611 \\
\hline Estonia & 0.664 & -0.0003 & 0.000402115 & 20.8 & 20675 \\
\hline Turkey & 0.792 & -0.0002 & 0.006284744 & 21.7 & 20658 \\
\hline Hungary & 0.740 & -0.0004 & $3.61709 \mathrm{E}-05$ & 18.4 & 20617 \\
\hline On the average & $x$ & -0.00033 & $x$ & 17.9 & 23645 \\
\hline Lithuania & 0.873 & -0.0007 & $2.47566 \mathrm{E}-08$ & 26.8 & 18508 \\
\hline Poland & 0.930 & -0.0007 & 4.94979E-11 & 20.8 & 18448 \\
\hline Latvia & 0.927 & -0.0009 & $7.9903 \mathrm{E}-11$ & 23 & 16564 \\
\hline Romania & 0.782 & -0.0009 & $6.27071 \mathrm{E}-06$ & 31.9 & 15322 \\
\hline Bulgaria & 0.894 & -0.001 & 4.13642E-09 & 22.4 & 12920 \\
\hline Colombia & 0.900 & -0.0009 & $2.76846 \mathrm{E}-05$ & 19.1 & 11298 \\
\hline South Africa & 0.687 & -0.001 & 0.00081319 & 26.3 & 10749 \\
\hline On the average & $x$ & -0.00087 & $x$ & 24.3 & 14830 \\
\hline Ukraine* & 0.928 & -0.0038 & $3.63002 \mathrm{E}-09$ & 53.9 & 7267 \\
\hline
\end{tabular}

*1999-2018

The statistics of the studied features in a number of highly developed countries over a longer period to verify this conclusion was used. The length of the time series will differ because the available OECD statistical resource is presented in this form (Table 4.).

Table 4. Study of the change in the size of the regression coefficient (b) in correlation analyzes of the connection between the share of the expenditures for food in the structure of the total expenditures of the households (\%) and GDP per capita (dollars USA) in the number of the highly developed countries in the relevant time intervals [14], [15]

\begin{tabular}{|l|c|c|c|c|c|}
\hline Country, time & $r$ & $\begin{array}{c}\text { Regression } \\
\text { coefficient, } b\end{array}$ & $p$-Value & $\begin{array}{c}\text { Average value } \\
Y, \%\end{array}$ & $\begin{array}{c}\text { Average value } x, \\
\text { dollars USA }\end{array}$ \\
\hline Australia 1959-1978 & 0.982 & -0.0006484 & $1.87862 \mathrm{E}-14$ & 15 & 19835 \\
\hline Australia 1979-1998 & 0.931 & -0.0002602 & $2.73988 \mathrm{E}-09$ & 11.9 & 28544 \\
\hline Australia 1999-2018 & 0.925 & -0.0001128 & $5.63417 \mathrm{E}-09$ & 9.9 & 42156 \\
\hline Canada 1981-1999 & 0.926 & -0.0005064 & $1.31495 \mathrm{E}-08$ & 11.4 & 30430 \\
\hline Canada 2000-2018 & 0.811 & -0.0000817 & $2.5383 \mathrm{E}-05$ & 9.3 & 40490 \\
\hline USA 1970-1993 & 0.981 & -0.0004355 & $4.37277 \mathrm{E}-17$ & 11.3 & 29911 \\
\hline USA 1994-2018 & 0.945 & -0.0000934 & $1.11256 \mathrm{E}-12$ & 7 & 46938 \\
\hline Denmark 1966-1991 & 0.985 & -0.0005337 & $6.08324 \mathrm{E}-20$ & 16.8 & 26814 \\
\hline Denmark 1992-2018 & 0.938 & -0.0001901 & $5.39569 \mathrm{E}-13$ & 11.8 & 41661 \\
\hline Finland 1975-1996 & 0.931 & -0.0007744 & $3.37328 \mathrm{E}-10$ & 19.2 & 23285 \\
\hline Finland 1997-2018 & 0.648 & -0.0000769 & 0.001102215 & 12.4 & 36595 \\
\hline France 1959-1988 & 0.993 & -0.0006544 & $4.03095 \mathrm{E}-27$ & 19.4 & 19321 \\
\hline France 1989-2018 & 0.888 & -0.0001692 & $5.9229 \mathrm{E}-11$ & 13.6 & 33794 \\
\hline Norway 1975-1996 & 0.974 & -0.0002755 & $2.0736 \mathrm{E}-14$ & 18.1 & 13.1 \\
\hline Norway 1997-2018 & 0.968 & -0.0003771 & $1.79941 \mathrm{E}-13$ & & 36723 \\
\hline
\end{tabular}


As we can see, the value of the regression coefficient (b) decreases while passing from the earliest to the latest time series in all represented highly developed countries except Norway. This can be considered as confirmation of our assumption on the identified pattern - the reaction of the share size of the expenditures for food in the structure of the total expenditures of the households to per capita GDP growth, corresponds to the law of diminishing returns (Fig. 1.). The pattern is manifested in the long-term period.

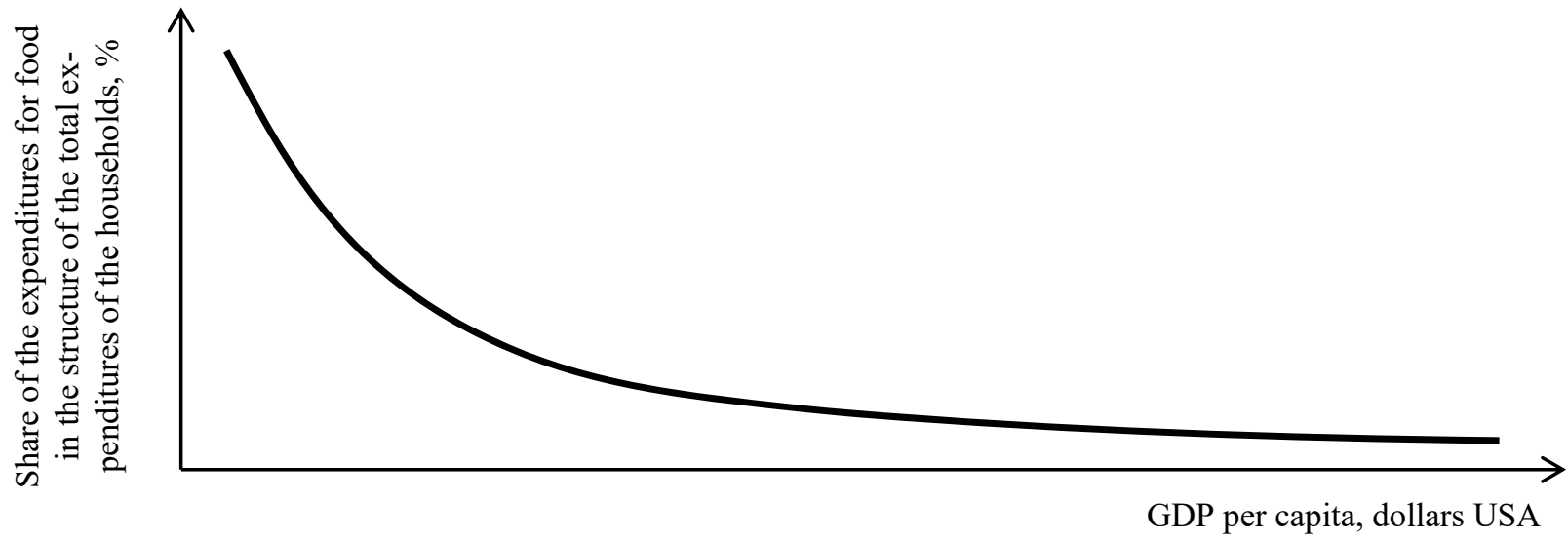

Figure 1. Effect of the law of diminishing returns in the case of a reduction in the share of the expenditures for food in the structure of the total expenditures of the households in response to per capita GDP growth*

* own working out of authors

Given the results of the correlation-and-regression analysis and analytical grouping (Table 3.), the fol-

the development of the national food system of lowing dependencies can be the marks for predicting
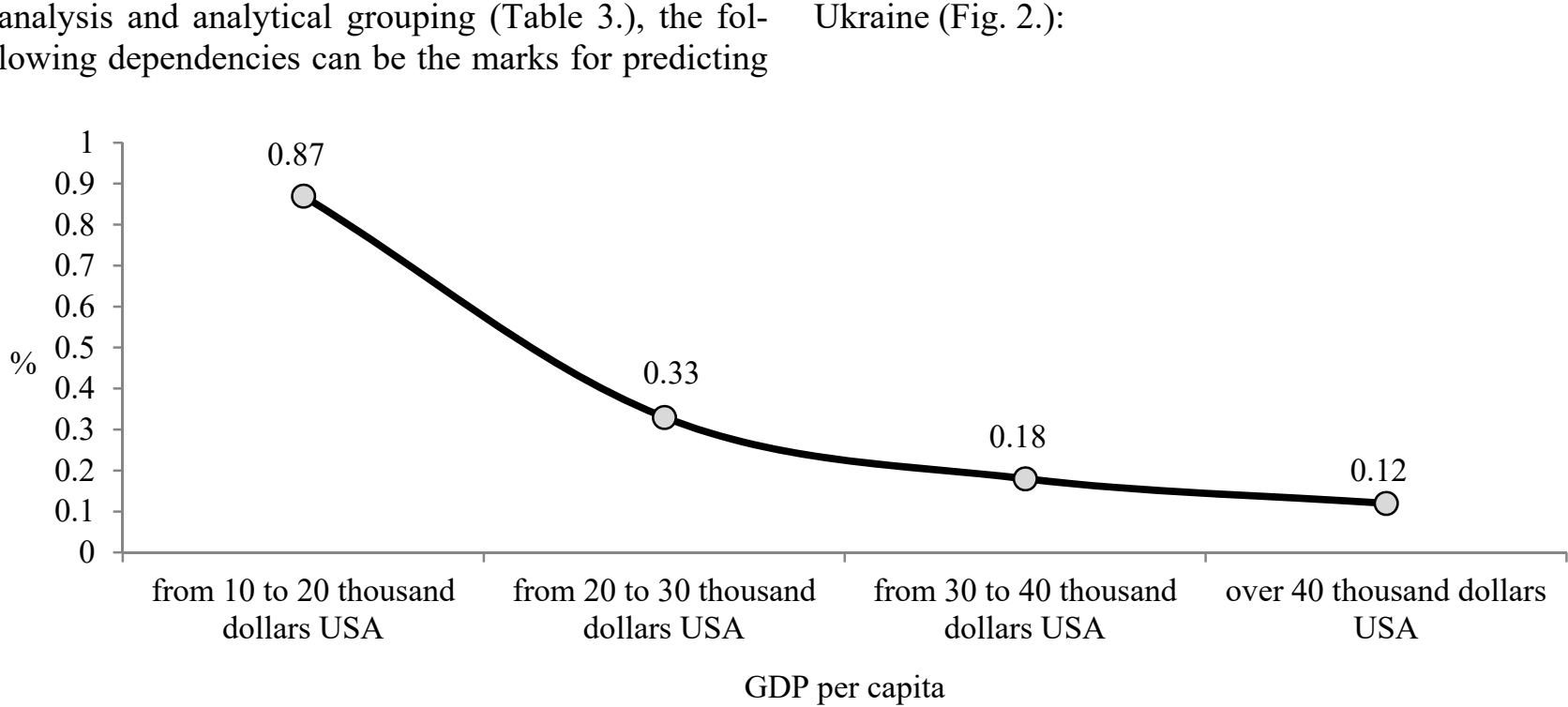

Figure 2. Probable decrease in the share of the expenditures for food in the structure of the total expenditures of the households in Ukraine in response to per capita GDP growth in \% for every \$1000 per capita GDP growth in certain ranges [14], [15]

1) the range of per capita GDP growth from 10 to 20 thousand dollars USA (by purchasing power parity, at constant prices): each increase of 1000 dollars USA leads to a reduction in the share of the expenditures for food in the structure of the total expenditures of the households by $0.87 \%$;

2) the range of per capita GDP growth from 20 to 30 thousand dollars USA (by purchasing power parity, at constant prices): each increase of 1000 dollars USA leads to a reduction in the share of the expenditures for food in the structure of the total expenditures of the households by $0.33 \%$;

3 ) the range of per capita GDP growth from 30 to 40 thousand dollars USA (by purchasing power parity, at constant prices): each increase of 1000 dollars USA leads to a reduction in the share of the expenditures for food in the structure of the total expenditures of the households by $0.18 \%$;

4) growth of per capita GDP over 40 thousand dollars USA (by purchasing power parity, at constant 
prices): each increase of 1000 dollars USA causes a reduction in the share of the expenditures for food in the structure of the total expenditures of the households by $0.12 \%$.

Predicting the change in the share of the expenditures for food in the structure of the total expenditures of the households, based on the prediction of

\section{Conclusion}

Ukraine is on the list of the countries with the problems on ensuring food security for its citizens. There are no problems with food availability in the country - all households consume food in energy equivalent, which is not below a certain threshold of the food security. Instead, there is a problem of low food affordability - the country's households spend more than half of their total expenditures for the food products, and are faced with a shortage of valuable products of animal origin and vitamin products.

It is found that there is a close connection between the food affordability and economic growth with the growth of GDP per capita, the share of expenditures for food and non-alcoholic beverages

\section{References}

[1]. Baldos, U. L. C., \& Hertel, T. W. (2016). Debunking the 'new normal': Why world food prices are expected to resume their long run downward trend. Global Food Security, 8, 27-38. https://doi.org/10.1016/j.gfs.2016.03.002

[2]. Breisinger, C., Van Rheenen, T., Ringler, C., Pratt, A. N., Minot, N., Aragon, C., ... \& Zhu, T. (2010). Food security and economic development in the Middle East and North Africa. International Food Policy Research Institute, 1-52.

[3]. Barrett, C. B. (2001). Does food aid stabilize food availability?. Economic development and cultural change, 49(2), 335-349.

https://doi.org/10.1086/452505

[4]. Chemin, M., Pelc, K., \& Perez-Aleman, P. (2019). Economic Growth and Food Security: Overlooked Opportunities at the Local, National, and International Level. Retrieved from: https://www.mcgill.ca/isid/files/isid/chemin.pelc_per ezaleman.pb3 .pdf [accessed: 13 March 2020].

[5]. Choudhury, S., \& Headey, D. (2017). What drives diversification of national food supplies? A crosscountry analysis. Global food security, 15, 85-93. https://doi.org/10.1016/j.gfs.2017.05.005

[6]. Ukrainy, P. K. M. (2007). Deiaki pytannia prodovolchoi bezpeky. №, 1379, 48. the economic growth in Ukraine, does not seem possible at the moment because of the COVID-19 pandemic. The latter caused the global economic crisis. It is possible to predict an increase in the food affordability for Ukrainian households only after its finishing, economic recovery and passing to the expansion phase.

decreases in the structure of the total expenditures of the households.

It is established that the reaction of the size of the share of the expenditures for food in the structure of the total expenditures of the households to the growth of per capita GDP corresponds to the law of diminishing returns. The pattern is manifested in the longterm period.

Currently, there is no possibility to predict the increase in food affordability for the Ukrainian households according to the prediction of the economic growth because of the global economic crisis caused by the COVID-19 pandemic.

[7]. Postanova Kabinetu Ministriv Ukrainy. (2016). «Pro zatverdzhennia naboriv produktiv kharchuvannia, naboriv neprodovol'chykh tovariv ta naboriv posluh dlia osnovnykh sotsial'nykh i demohrafichnykh hrup naselennia». [Resolution of the Cabinet of Ministers of Ukraine "On Approval of Food Sets, Sets of NonFood Products and Sets of Services for the Major Social and Demographic Groups"]. Dated f October 11, 2016 r. № 780. Ofitsijnyj visnyk Ukrainy, 2016. № 89. 22

[8]. FAO, IFAD, UNICEF, WFP, WHO. (2019). The state of food security and nutrition in the world 2019: safeguarding against economic slowdowns and downturns. Retrieved from: https://docs.wfp.org/api/documents/WFP0000106760/download/ [accessed: 20 April 2020].

[9]. Gödecke, T., Stein, A. J., \& Qaim, M. (2018). The global burden of chronic and hidden hunger: Trends and determinants. Global food security, 17, 21-29. https://doi.org/10.1016/j.gfs.2018.03.004

[10]. Gross, R., Schoeneberger, H., Pfeifer, H., \& Preuss, H. J. (2000). The four dimensions of food and nutrition security: definitions and concepts. $S C N$ News, 20(20), 20-5.

[11]. Haug, R. (2018). Food security indicators: How to measure and communicate results. Norwegian University of Life Sciences Faculty of Landscape and Society. 
[12]. Martinez, B. S. \& Colmenero, A. G. (2015). Analysis of the impact of globalization and economic growth on food security in developing countries. Madrid, Departamento de Economia Agraria, Estadística y Gestión de Empresas; Escuela Técnica Superior de Ingenieros Agrónomos Universidad Politécnica de Madrid.

[13]. Mudrak, R. (2014). Consumer Behavior As A Factor Of The Household's Food Security. Economic Annals$X X I$.

[14]. OECD .(2020). Final consumption expenditure of households. Retrieved from: https://stats.oecd.org/Index.aspx?DataSetCode=SNA TABLE5 [accessed: 25 April 2020].

[15]. OECD (2020). Gross domestic product (GDP): GDP, US \$, constant prices, constant PPPs, reference year 2010, millions. Retrieved from: https://stats.oecd.org/OECDStat Metadata/ShowMeta data.ashx?Dataset=SNA TABLE1\&ShowOnWeb=tru e\&Lang=en [accessed: 25 April 2020].

[16]. Pourreza, A., Geravandi, S., \& Pakdaman, M. (2018). Food Security and Economic Growth. Journal of Nutrition and Food Security, 3(3), 113-115.

[17]. Remans, R., Wood, S. A., Saha, N., Anderman, T. L., \& DeFries, R. S. (2014). Measuring nutritional diversity of national food supplies. Global Food Security, 3(3-4), 174-182. https://doi.org/10.1016/j.gfs.2014.07.001

[18]. Seheda, S., Datsenko, A., Otkalenko, O., \& Musil, P. (2019). The agrarian food consumption in Ukraine and its association with socio-demographic indicators of human development. Economic Annals-XXI, 175. https://doi.org/10.21003/ea.V175-08

[19]. Stamoulis, K. G. \& Zezza, A. (2009). Socioeconomic policies and food security, Encyclopedia of Life Support Systems (The Role of Food, Agriculture, Forestry and Fisheries in Human Nutrition, Vol. III, pp. 227-253). Oxford, United Kingdom: Eolss Publishers Co. Ltd.
[20]. State Statistics Service of Ukraine (2019). Expenditure and resources of households of Ukraine. Retrieved from:

http://www.ukrstat.gov.ua/druk/publicat/Arhiv_u/17/ Arch_vrd zb.htm [accessed: 13 June 2020].

[21]. Stezhko, N. (2016). Global indices in assessment of the global food problem and its impact factor. Економічний часопис-XXI, 161(9-10), 18-22. https://doi.org/10.21003/ea.V161-04

[22]. Swietlik, K. (2018). Economic growth versus the issue of food security in selected regions and countries worldwide.Problems of Agricultural Economics, 3(356). https://doi.org/ 10.30858/zer/94481

[23]. The Economist. (2019). Global Food Security Index. Retrieved from: https://foodsecurityindex.eiu.com [accessed: 27 April 2020].

[24]. The Parliamentary Office of Science and Technology (2006). Food security in developing countries, 274. London: UK Parlament. Retrieved from: https://www.parliament.uk/documents/post/postpn274 .pdf [accessed: 28 April 2020].

[25]. Timmer, C. P. (2005). Food Security and Economic Growth: an Asian perspective. Asian-Pacific Economic Literature, 19(2), 1-17. https://doi.org/10.1111/j.1467-8411.2005.00155.x

[26]. van Dijk, M., Gramberger, M., Laborde, D., Mandryk, M., Shutes, L., Stehfest, E., ... \& Faradsch, K. (2020). Stakeholder-designed scenarios for global food security assessments. Global Food Security, 24, 100352. https://doi.org/10.1016/j.gfs.2020.100352

[27]. World Bank. (2019). GDP per capita, PPP (constant 2011 international \$). World Development Indicators (WDI), Data Catalog. Retrieved from: http://api.worldbank.org/v2/en/indicator/NY.GDP.PC AP.PP.KD?downloadformat $=$ excel [accessed: 28 April 2020]. 